DOI http://dx.doi.org/10.4314/mlr.v7i1.8

\title{
MOTOR VEHICLE LESSORS’ LIABILITY FOR Damages To Third PARTiEs: A COMMENT
}

Abrar Sabir v W/ro Alemtsehay Wesene \& Tibebu Construction PLC

Hailegabriel G. Feyissa *

\section{Introduction}

Amidst deteriorating road safety and increased motor vehicle accidents, litigations involving Article 2081 et seq. of the Ethiopian Civil Code appear to have increased in the last few years. Interesting court decisions involving, among other things, the scope of the strict liability rules of the Ethiopian extracontractual liability law, are now coming into sight. While the black letters of the law are not necessarily clear on the specific scope of Article 2081 et seq. of the Civil Code, courts ${ }^{1}$ and academics ${ }^{2}$ have been reflecting on the tricky subject of defining the scope of application of the Ethiopian law on liability for damages caused by motor vehicles.

In entertaining issues related to Article 2081, the Cassation Division of the Federal Supreme Court in a recent case has rendered a decision that allows

* LLB (Bahir Dar University), LLM (University of Groningen), PhD Student (The University of Melbourne). Formerly, the author was assistant professor of law at Law School, Bahir Dar University.

${ }^{1}$ E.g., Negist Makonnen et al. v Ethiopian Airlines et al., Addis Ababa High Court Civil Case No. 701/55 E.C.

${ }^{2}$ See, e.g.,Krzeczunowicz, G. (1970) The Ethiopian Law of Extra-Contractual Liability. Addis Ababa, Haile Selassie I University, p.166 [hereinafter Krzeczunowicz]; Krzeczunowicz, G. (1977)The Ethiopian Law of Compensation for Damage. Addis Ababa, Commercial Printing Enterprise, pp. 170 and 238 [hereinafter



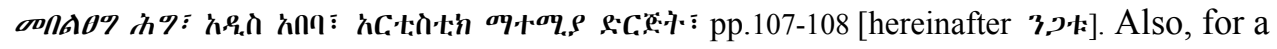
recent reflection on the scope of Article 2081 of the Ethiopian Civil Code see HailegabrielF. (2011) "The Scope of Article 2081 of the Civil Code: A Comment on Negist Makonnen et al v. Ethiopian Airlines, Inc."Bahir Dar University Journal of Law, 2(1), pp.153-158 (Also indexed in Public International Law eJournal, Vol. 7, No. 59, May 7, 2012) [hereinafter Hailegabriel]. 
owners of leased motor vehicle to escape strict liability (i.e. liability without fault) under certain circumstances. Taken aback by the Cassation Bench's decision relieving the owner of motor vehicle from liability, I would in this short comment explain why the Bench got it wrong and how the precedent (for binding interpretation) it set would incorrectly limit the right of the injured to hold the lessor responsible.

\section{Summary of the Case}

\section{Abrar Sabir v W/roAlemtsehay Wesene \& Tibebu Construction PLC ${ }^{3}$}

On 25 Tikimit 1996 E.C. (November 5, 2003), a Hilux Toyota, carrying Ato Abraham Aklil, collided with a tree near Sherera Kebele. Ato Abraham, who was seriously injured in the accident, died on 03 Tahsas 1996 (December 13, 2003) despite some medical care. W/ro Alemtsehay Wesene, his widow, sued Ato Abrar Sabir, the owner of the motor vehicle for damages.

Before the High Court of Arsi Zone - the court that initially entertained the case - the defendant argued that he should not incur extra-contractual liability for the motor vehicle was leased to Tibebu Construction PLC. ${ }^{4}$ Nonetheless, the court held the lessor of the vehicle liable. On appeal, the Supreme Court of Oromia National Regional State affirmed the decision of the lower court as regards liability, even if it reduced the amount of compensation awarded to the claimant. ${ }^{5}$ The Federal Supreme Court of Ethiopia dismissed Ato Abrar's appeal for it agreed with the judgment appealed from. Finally, Ato Abrar submitted a cassation petition to the Cassation Division of the Federal Supreme Court for review of the judgment rendered by the lower courts on grounds of fundamental error of law. The highest judicial authority, unlike the lower courts, agreed with the petitioner that the lessee (Tibebu Construction PLC) would be liable notwithstanding the fact that the driver of the leased car is employed by the lessor under the lease agreement. Quoting ${ }^{6}$ from the opinion:

Save where damage is caused while the vehicle is stolen, the owner of motor vehicle is liable under Article 2081 of the Civil Code for damage caused by it irrespective of the fact that the damage is caused by a person who is not authorized to operate or drive the vehicle. Yet, a holder is also liable for

\footnotetext{
${ }^{3}$ Abrar Sabir v W/ro Alemtsehay Wesene \& Tibebu Construction PLC, Federal Supreme Court of Ethiopia, Cassation File No.55228 [January, 2011; reported in PanC:

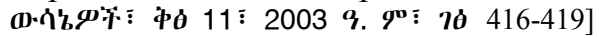

${ }^{4}$ Upon the request of Ato Abrar Sabir, the lessee was later joined as defendant in the suit as per Article 43 of the Civil Procedure Code.

${ }^{5}$ While W/ro Alemtsehay claimed 138,400.00 birr in damages, the High Court of Arsi Zone awarded her only Birr 40,000.00. The Supreme Court of Oromia National Regional State further reduced this sum to Birr 25,000.00.

${ }^{6}$ Translation by the author.
} 
damages caused by the vehicle in his holding. Accordingly, the owner and holder of the vehicle are jointly and severally liable. Moreover, the owner is entitled under Article 2083 of the Civil Code to be indemnified by the holder if the former alone has paid compensation to the victim. The petitioner was sued because he was the owner of the vehicle causing the accident. Upon the petitioner's request, the second respondent was joined as defendant during the trial for it was the lessee of the vehicle during the accident. Though the driver of the rented car was employed by the owner, Article 2082 of the Civil Code does not relieve the holder [lessee] from liability for the mere reason that the driver is accountable to the lessor. The holder is thus liable for the law places ultimate liability on him. The decision of the lower courts that relieved the lessee from liability and held the appellant (lessor) solely liable for the damage was not in accord with the content and spirit of the provisions of Articles 2081, 2082(1) and 2083 of the Civil Code; and hence involves fundamental error of law. ${ }^{7}$

In light of the above reasoning, the court ordered the lessee of the motor vehicle to redress the damage $\mathrm{W} /$ ro Alemtsehay Wesene sustained.

\section{Applicable Law}

Abrar Sabir v W/ro Alemtsehay Wesene \& Tibebu Construction PLC involves the interpretation of Articles 2081-2083 of the Ethiopian Civil Code. As the

7 The Amharic version of the excerpts reads as follows:

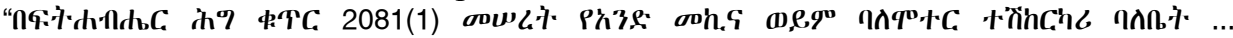

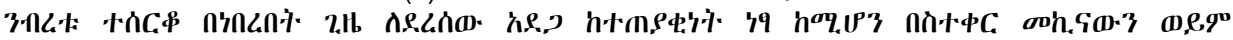

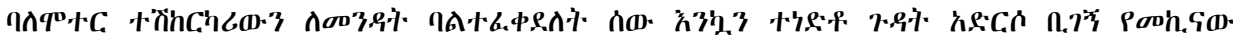

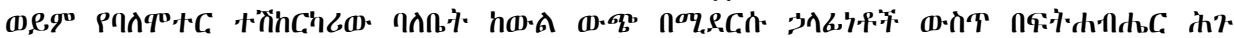

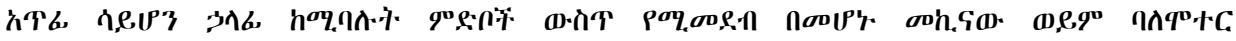

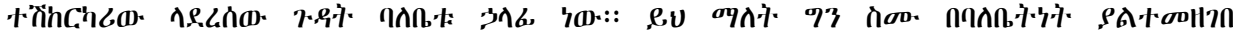

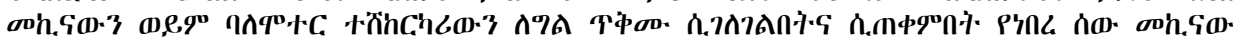

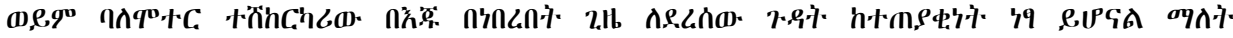

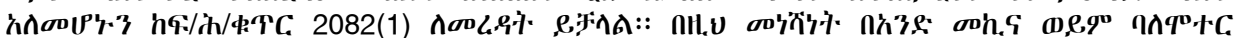

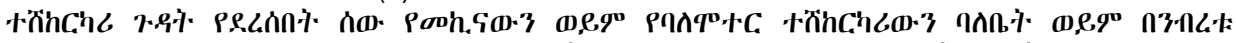

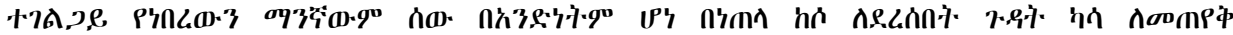

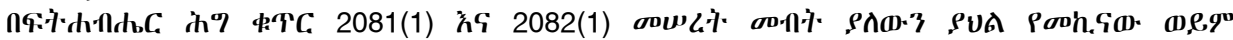



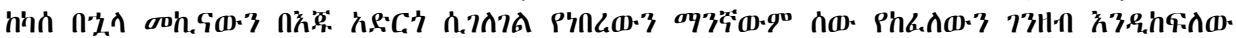

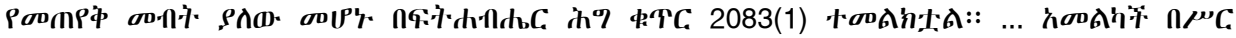

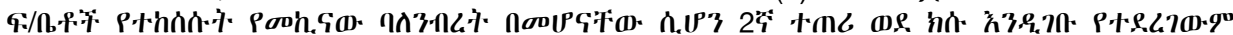

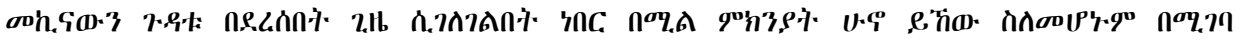

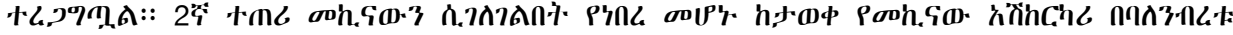

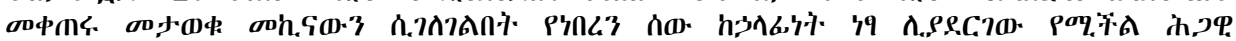

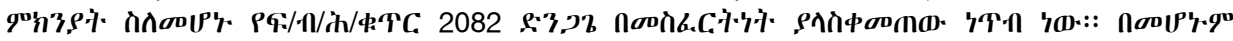

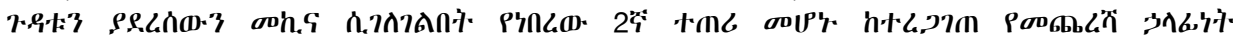

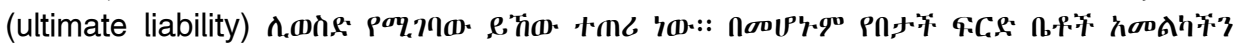

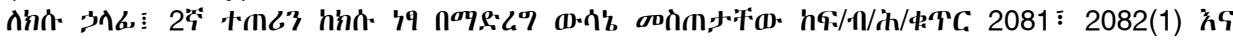

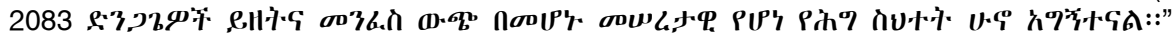


lessor and lessee of the motor vehicle involved in an accident are joined as defendants, it also calls for the application of Article 43 of the Civil Procedure Code.

While Article 2081 sets the principle that an owner of a motor vehicle is strictly liable for any damage caused by the vehicle, Article 2082 places similar liability on holders ${ }^{8}$ of the motor vehicle. Article $2083^{9}$ deals with transfer of liability, and states that the owner who has paid compensation to the victim may recover from the holder.

An understanding of "holder" requires a look at the provisions of Article 2072 of the Civil Code. Anyone who receives a vehicle for personal benefit is a holder. In particular, a person who has taken a rental car or borrowed the vehicle is liable for any damage caused by the vehicle in his holding. According to Krzeczunowicz, holder under Ethiopian law is different from custodian under French law. ${ }^{10}$ Hence, "the French requirement of 'controlling' powers" in the determination of whether the custodian is liable is irrelevant. ${ }^{11}$

\section{Comments}

The Federal Supreme Court Cassation Bench's decision in Abrar Sabir v W/ro Alemtsehay Wesene \& Tibebu Construction PLC (1) involves joinder of a lessor and a lessee of a motor vehicle as defendants in a strict liability suit, and (2) distinguishes "holder" from "custodian." In this section, I argue that the decision of the court to allow joinder of the lessee as defendant and to finally place sole responsibility on the lessee is wrong. Moreover, the court's rejection of the lower courts' reasoning that 'the fact that the motor vehicle involved in the accident was being driven by an employee of the lessor should entail strict liability of the lessor" can be challenged.

${ }^{8}$ The caption of Article 2082, i.e., keeper or agent, is translated to mean holder or employee by George Krzeczunowicz. Here, we use the term holder as opposed to keeper to refer to the lessee of motor vehicle. See,Krzeczunowicz, supra note 2, p. 168.

${ }^{9}$ In particular, the authoritative Amharic version of Article 2083(1) reads: "Porh.Go.

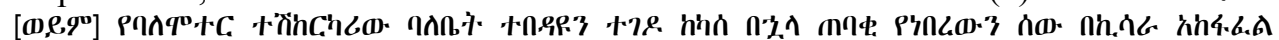

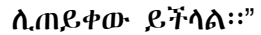

${ }^{10}$ Krzeczunowicz, supra note 2, p. 43.

${ }^{11}$ But see NegistMakonnen et al. v Ethiopian Airlines et al., supra note 1, where the court emphasised the importance of control in determining the liable person for damages caused by airplane accident.For more on the strict liability of the custodian under French law, see, e.g. Wagner G., "Custodian Liability in European Private Law", in Oxford Handbook of European Private Law (Basedow, Hopt, Zimmermann eds., Oxford University Press forthcoming). 
Vol. 7 No.1, September 2013

\subsection{Whether Third Party Practice Exonerates Joint and Several Liability}

Article 43 of the Civil Procedure Code allows joinder of a third party defendant "where the defendant 'claims to be entitled to contribution or indemnity' from that person". ${ }^{12}$ This principle aims at "prompt dispatch of litigation" through the management of different but related cases together. ${ }^{13}$ Accordingly, a defendant's claim for contribution or indemnity against the third party is entertained in a single suit together with the plaintiff's claim against the original defendant.

Apparently, the effect of joinder of a third party defendant under Article 43(1) does not seem to affect the claims of the plaintiff against the original defendant. While Article 43(3) simply states "the claim as between the defendant and the third party shall be tried in such manner as the court shall direct," the law is not clear whether the plaintiff may make any claim against the third party or vice versa. In light of the jurisprudence in common law jurisdictions, Robert Sedler opines that courts should "not adjudicate any claim

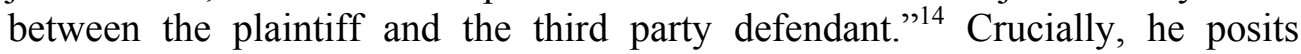
joinder of a defendant under Article 43 does not ipso jure free the original defendant from liability whatsoever:

[T] he claim of the defendant against the third party defendant does not affect the plaintiff's claim at all, and there is no provision authorising the third party defendant to make any claim against the plaintiff. The court merely adjudicates the question of indemnity or contribution between the defendant and the third party defendant, and the third party defendant may assert any defences he has against the defendant. If the defendant is found to be entitled to contribution or indemnity against the third party defendant, a decree will be entered in his favour. The decree imposes an obligation against the third party defendant to the defendant, but no obligation [is imposed] against him in favour of the plaintiff. If the third party defendant refuses to pay the plaintiff directly, the plaintiff will proceed against the defendant, and the defendant cannot object on the ground that a decree was entered in his favour against the third party defendant. By the same token, the plaintiff is not entitled to enforce his decree against the third party defendant". ${ }^{15}$

In Abrar Sabir v W/ro Alemtsehay Wesene \& Tibebu Construction PLC, the Cassation Bench allowed the lessor - the original defendant - to be relieved

\footnotetext{
${ }^{12}$ Sedler, R., (1968) Ethiopian Civil Procedure. Addis Ababa, Haile Selassie I University Press, p.87 [Hereinafter Sedler]

${ }^{13}$ Ibid.

${ }^{14}$ Ibid.

${ }^{15}$ Ibid, p.92.
} 
from liability notwithstanding the fact that he was jointly and severally ${ }^{16}$ liable with the lessee, i.e., the third party defendant. In placing sole responsibility on the lessee, the Bench rendered a decree that imposes an obligation against the third party defendant to the plaintiff. The Bench re-affirmed its position in another recent case, Nile Insurance SC v. Ato Agegnehu Geremew, et al. ${ }^{17}$ in

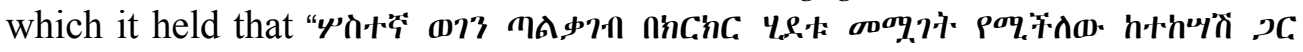
ก; "ו not only against the defendant"). This defies Sedler and comparable jurisprudence on third party practice elsewhere.

The implication of this line of interpretation of Article 43 of the Civil Procedure Code is also far reaching. It does not only result in a decree that imposes an obligation against the third party defendant to the plaintiff; it may also unfairly jeopardise the claims of the plaintiff against the original defendant in the suit. The supreme judicial authority in Ethiopia has not given due attention to the qualification under Article 43 that any interpretation of the rule on third party practice should be undertaken in a manner that does not "prejudice the plaintiff against any defendant in the suit". ${ }^{18}$

In Abrar Sabir v W/ro Alemtsehay Wesene \& Tibebu Construction PLC the Bench did not apparently bother if its interpretation of a procedural rule may affect a substantive right of the plaintiff. As rightly pointed out by Sedler, ${ }^{19}$ Ethiopian substantive law (not procedural law) governs whether a defendant (who requests for a joinder of a third party defendant under Article 43 of the Civil Procedure Code) is entitled to contribution or indemnity. And, Ato Abrar's application for the joinder of Tibebu Construction PLC as a co-defendant in a strict liability suit must be scrutinized in light of Articles 2083 and 2155 of the Civil Code.

While Article 2155 of the Civil Code underscores that an owner and a holder (for our purpose, lessor and lessee) are jointly and severally liable, ${ }^{20}$ the rules in Article 2083 entitle the owner who has paid compensation to the victim to be indemnified by the holder. The owner may be indemnified in full except where

${ }^{16}$ According to Krzeczunowicz, this distinguishes the Ethiopian law from its French counterpart where the liability of the holder is alternative to the owner; see Krzeczunowicz, supra note 2, pp.43-44.

${ }^{17}$ Nile Insurance SC v Ato Agegnehu Geremew, et al, Federal Supreme Court, Cassation File No. 79465 (Tir 14, 2005 Ethiopian Calendar, forthcoming in Ponnc a·d'b 14 ¿ 2005 9. $\mathbf{9}^{\mathbf{0}}$ )

${ }^{18}$ This writer believes the rule in sub article 4 of Article 43 regarding a claim (for contribution or indemnity) by a defendant against any co-defendant applies whether or not the co-defendant is already a party.

${ }^{19}$ Sedler, supra note 11, p. 88.

${ }^{20}$ On the relevance of Article 2155 for cases involving strict liability for damages caused by motor vehicle accidents, see Krzeczunowicz, supra note 2, pp.43-44. 
he or a person for whom he is vicariously responsible is at fault. The literal interpretation of Article 2083 implies that a motor vehicle owner may avail himself of his right to indemnity only when he has first paid the damage to the victim. ${ }^{21}$ Moreover, the principle of joint and several liability does not allow a lessor (owner) of motor vehicle to simply shy away from liability for the mere reason that somebody has leased the vehicle. It is against this backdrop of substantive rules that I maintain that the Cassation Division of the Federal Supreme Court should have entered a decree in favour of W/ro Alemtsehay against Ato Abrar. ${ }^{22}$ The procedural rule for third party practice is not created for the purpose of allowing a defendant who is liable to avoid joint and several liability; it is rather created for the purpose of achieving efficiency in civil litigation.

\subsection{Lessee’s Liabilitay Notwithstanding Driver Employed by Lessor}

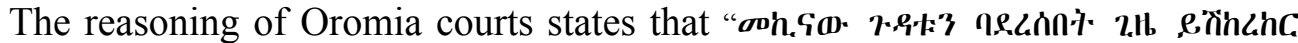

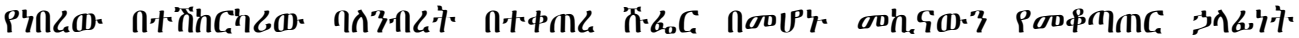

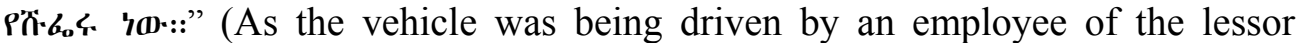
during the infliction of harm, it was the driver who was in control of the vehicle). In trying to link possession with responsibility, Oromia courts ignored the apparent uniqueness of Ethiopian law on holder's liability. They interpreted motor vehicle holder to mean anyone who controls and directs the vehicle and for that reason assumes extra-contractual responsibility.

This line of interpretation contradicts the presumed intention of the legislator. According to Krzeczunowicz, Ethiopia's conception of holder is different from that of custodian under numerous French-inspired European tort laws. In France and some other European jurisdictions, strict liability is placed on custodian -

${ }^{21}$ However, this would make the procedural rule under Article 43 "ineffective". For more on the inconsistency between Article 43 of the Civil Procedure Code and the Civil Code rules on contribution and indemnity, see Sedler, supra note 11, pp. 88-89.

${ }^{22}$ Even when one holds that a decree must be entered against a third party defendant (the lessee in our case), it must still maintain a decree against the original defendant. I am not that much orthodox on Sedler's idea that the defendant's claim against the third party defendant is treated as if it were a separate claim. I am primarily concerned by the ruling of the bench that a claimant in a motor vehicle accident suit should be compensated just by one of the two co-defendants, not by both of them as the rule on jointly and severally dictates. Note however that I am not against part of the bench's reasoning that goes "ү.,

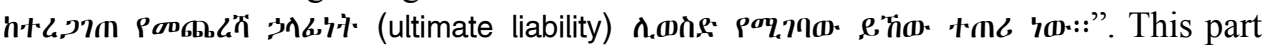
of the bench's reasoning is interesting, but beside the point if not well articulated. 
someone who controls and directs the motor vehicle. Depending on the facts of the case, a lessor or a lessee would be a custodian for strict liability purposes. In contrast, Ethiopian law places strict liability on the holder - someone who takes hold of a rented car, borrows, or receives a vehicle from the owner for his own benefit. The law does not require tort claimants to establish "controlling power" to establish the strict liability of the holder. What the law requires is the establishment of some economic or alternatively juridical elements enumerated under Article 2072 of the Civil Code.

In view of the foregoing, the Federal Supreme Court's Cassation Bench is apparently right to ignore the reasoning of the lower courts that strict liability for motor vehicle accidents presupposes control or direction. As the literal reading of the law dictates, the lessee remains responsible for third party damages irrespective of the fact that actual control of the vehicle belongs to the lessor or its agent.

Equating "holder" to "lessee" of any sort is also problematic. First, the provisions of Article 2081 of the Civil Code generally apply to motor vehicles including vessels and aircrafts. ${ }^{23}$ Motor vehicle rentals - which are not adequately regulated under the Civil Code - place importance on "control" for the purpose of third party liability. As I have argued elsewhere, ${ }^{24}$ the type of lease contract may matter in the distribution of responsibility [for accidents involving the leased vehicle] among the lessor and lessee. For instance, a standard long-term car rental contract between Chinese construction companies and Ethiopian lessors usually include stipulations to the effect that the lessor shall be responsible for insurance relating to the car and the driver and all kinds of accidents involving the vehicle. ${ }^{25}$ Moreover, within the context of maritime and air law, the relationship between the lessor and the lessee is mainly governed by a "highly standardized and negotiated" contract of lease which is often sensitive to the issue "who controls the ship or the aircraft" so that responsibility for accidents be dealt with fairly. ${ }^{26}$

In line with the tradition of distinguishing various types of vehicle lease contracts for the purpose of liability, an Ethiopian court rendered a decision ${ }^{27}$ that merits acclaim for its analytic rigor. Apart from expressly recognizing the application of Article 2081 et seq. of the Civil Code to aerial motor vehicles, it

\footnotetext{
${ }^{23}$ For more on this, see Hailegabriel, supra note 2, pp. 153-158.

${ }^{24}$ Hailegabriel F. (2011), "A Legal Appraisal of the Liability of the Actual Air Carrier under Ethiopian Law" Bahir Dar University Journal of Law, 2 (1), pp. 85-101 [hereinafter Hailegabriel on Actual Air Carrier].

${ }^{25}$ Hunan Huanda Road \& Bridge Corporation, Dansha-Dejena-AdiRemet Road Project Office, Ethiopia, Equipment Rental Contract, on file with the author.

${ }^{26}$ For more on this, Hailegabriel on Actual Air Carrier, supra note 23, pp.94-97 and the accompanying footnotes.

27 See Negist Makonnen et al. $v$ Ethiopian Airlines et al., supra note 1.
} 
emphasized the importance of "control" in establishing who between the lessor and the lessee is liable for damages to third party. The application of the reasoning of the court (in Negist Makonnen et al. $v$ Ethiopian Airlines et al.) to our present case would render Ato Abrar Sabir liable because the driver was employed by him. As seen above, however, the Ethiopian law does not necessarily require "control" for the purpose of establishing the liability of motor vehicle owners/lessors. All it requires is the establishment of the economic or juridical elements listed in Article 2072 of the Civil Code.

The writer is of the opinion that "control" may still be important. Crucially, when (1) the contract of lease places responsibility for damages on the party who controls the vehicle, and (2) the motor vehicles involved are aircrafts and vessels, courts should look into who controls the vehicle before identifying the party responsible for damages caused by motor vehicle accidents.

Although literal interpretation of Article 2072 renders the lessee liable, the Code's indifference to the various types of motor vehicle lease agreements dissuades us from interpreting the term "hire" broadly. A very careful interpretation of "hire" is particularly important vis-à-vis aircraft and vessel lease agreements with respect to which there is a long established tradition of leaving matters related to liability for accidents to the parties themselves. Moreover, legislation and jurisprudence ${ }^{28}$ recognize the importance of differentiating between various types of lease contracts so as not to unduly surprise an unsuspecting lessee or lessor who relies on the principle of freedom of contract in solving such matters.

\section{Conclusion}

The interpretation of Article 2081 by the Cassation Division of the Federal Supreme Court matters not only because it uncovers the scope of a very important statutory rule whose confines are not clear, but also because literal interpretation ends up defeating legitimate expectations of the parties involved in motor vehicle lease agreements. The holding of the court in Abrar Sabir $v$ W/ro Alemtsehay Wesene \& Tibebu Construction PLC also appears far-reaching as part of the reasoning, as stated earlier, is sustained in another case -Nile Insurance SC $v$ Ato Agegnehu Geremew, et al.

The writer maintains that the Cassation Bench's reasoning in Abrar Sabir $v$ W/ro Alemtsehay Wesene \& Tibebu Construction PLC is problematic for it

${ }^{28}$ For a comparative overview of the law and jurisprudence on the liability for motor vehicle accidents, see Stone, F. (1970) "Liability for Damage Caused by Things", in Tunc, A. et al. (eds.) The International Encyclopedia of Comparative Law. The Hague, MartinusNijhoff Publishers, Vol. XI, Chapter 5; see also Weir, T. (1983) "Complex Liabilities", in The International Encyclopedia of Comparative Law. The Hague, MartinusNijhoff Publishers, Vol. XI Torts, Chapter 12. 
allowed a procedural rule to override a substantive right. Admittedly, the interpretation of a procedural rule of Anglo-Indian origin in light of a substantive doctrine of continental origin is not easy. Yet, it is my contention that the procedural rule for third party practice should not be interpreted in a manner that allows a lessor to escape joint and several liability and leave a claimant with lesser chances of redress than the substantive law affords her.

Moreover, the court's reasoning that the lessee is solely liable for accidents caused by the leased motor vehicle is indifferent to the practice in the lease industry that differentiates various types of motor vehicle lease agreements. Although the court may be right in ignoring the importance of "control" for the purpose of identifying the holder under Article 2082, a literal interpretation appears to defeat the legitimate expectation of parties to motor vehicle lease agreements who usually stipulate contractual provisions regarding liability for accidents caused by the leased vehicle. 